\title{
STUDIES ON ROLE OF TICKS IN TRANSMISSION OF SOME BLOOD PARASITES IN CAMEL
}

\author{
El-seify, M.A ${ }^{1}$., Ebrahaium, A.A ${ }^{2}$, Hashem,M.A ${ }^{3}$., Kamel,Z.M ${ }^{4}$. \\ 1) Parasitology Department, Faculty of Veterinary Medicine, Kafrelsheikh, University. \\ ${ }^{2)}$ Poultry Diseases Department, Faculty of Veterinary Medicine, South Valley University. \\ 3) Animal Health Research Institute, Parasitology Department, Mansoura branch. \\ 4) Animal Health Research Institute, Parasitology Department, Aswan branch.
}

\section{ABSTRACT}

This study was carried out in the imported camels that enter Egypt coming from Sudan those were passed on Abu-Simbuel region (AbuSimbuel Abatoir) of Aswan Governorate, southern Egypt in the period from November, 2015 to October, 2016, to identify tick species infesting camels, study the prevalence of ticks infestation in camels all over the year andthe prevalence of Trypanosoma and microfilaria infection of camels, also the role of ticks in transmission of Trypanosoma species. The overall prevalence in the tick infestation was recorded as (60.96\%) (1463/2400). The higher infestation were recorded in November, December (2015) and January (2016) and lower infestation were recorded in June.A total of (960) ticks were collected from the infested camels and identified. Hyalomma dromedarii was the predominant tick species and comprised (83.54 $\%)$ of the collected ticks. Other tick species found in very low numbers were Rhipicephalus praetextatus(4.27 \%), Hyalomma anatolicum anatolicum (3.85\%), Hyalomma impeltatum (2.92\%), Rhipicephalus sanguineus (2.29 \%),Hyalomma anatolicum excavatum(1.35\%), Hyalomma marginatum rufipes (1.12\%), and Hyalomma truncatum (0.63\%).(99) blood samples from (4800) collected blood samples was infected by Trypanosoma evansi and hence constitute a prevalence rate of $(2.0625 \%)$, with highest prevalence rate infection was (8.5\%) in October, alsofounded that (2) blood samples from( 4800) samples that infected by microfilaria in February and December (winter) with prevalence rate $(0.042 \%)(2 / 4800)$. We founded two samples in gut of male ticks contain developed stages of Trypanosoma in (March and June).

Key words: Camels, Ticks,Trypanosoma,Microfilaria,Transmission. 


\section{INTRODUCTION}

Ticks are blood-sucking ectoparasitic arthropods that transmit many pathogens of livestock, including bacteria, protozoa, and viruses (Barker \& Murrell, 2004; Jongejan \& Uilenberg, 2004). Camels in Egypt were found to be mainly infested by Hyalomma dromedarii (95\%) together with Hyalomma marginatum subspecies, Hyalomma anatolicum excavatum and Hyalomma species nymphs (Van Straten \& Jongejan 1993). In the same area and on the same animal species $\boldsymbol{E l}$ Kady\& Shouky (2001) reported that $H$. dromedarii; Hyalomma impeltatum, $H$. a. excavatum and H. a. anatolicum represented $96 \%$ of the tick population with higher infestation in March to November and a mean monthly total of 22-78 ticks per animal.

In Sudan, Karrar et al., (1963) reported that H.dromedarii was the main tick species of camels together with Amblyomma lepidum, $H$. impeltatum, Rhipicephalus sanguineus sanguineus, Rhipicephalus simus, H. a. excavatum, $H$. truncatum and $H$. m. rufipes.

Blood parasites especiallyTrypanosoma spp. and filaria spp. are known to affect the health of camels leading to anemia, wasting and death in heavy infection (Jorgen \& Brian, 1990). Trypanosoma infection (surra) is a serious disease affecting a camels (Desquesnes et al., 2013), results in high mortality and the reduced fertility, generalized loss of body condition, anemia, and eventual death (Luckins, 1998). Trypanosomes are parasites transmitted by ectoparasites such as the tsetse fly, Tabanidae (horse flies), and by various ticks (Magona et al. 2009; Burgdorfer et al. 1973). Also in study made by Hussein et al., 2009 during examination of some ticks for parasites that may infect livestock in Saudi Arabia, Trypanosoma developmental stages were

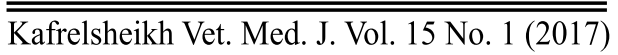


found in the tick Hyalomma dromedarii salivary glands (unpublished data). However, many tabanid flies were observed feeding on camels in the regions where camels showed infection with $T$. evansi.

The most famous Microfilarial infection that infest camel is Dipetalonema evansi, a parasite of the pulmonary arteries, mesentery and lymph vessels, (Fassi-Fehri,1987), recorded in Saudi Arabia, Iran and Egypt (Wernery \& Kaadan,2002). It appeared as a snake like with a rapidly, forward movement across the microscopic field in wet smear while in Giemsa stained smears showed a coiled or twisted appearance, (Hashem.M.A et al.,2008).

This work is aimed to; Study the prevalence of tick's infestation in camels all over the year, identification of tick's species that infest camels and incidence rate of each species, the prevalence of Trypanosoma and microfilaria infection of camels in Aswan and the role of ticks in transmission of Trypanosoma species.

\section{MATERIALS AND METHODS}

The study made on imported camels that enter Egypt coming from Sudan those were passed on Abu-simbuel region (Abu-simbuel Abatoir) of Aswan Governorate, Southern Egypt in the period from November ,2015 to October, 2016.

\section{Collection and examination of blood samples:}

Blood samples were randomly collected each season from camels (imported camels of different ages).We were collected 4800 Blood samples from the jugular vein of each camel using EDTA vacationers (Ethylene diamine tetra acetic acid as anti-coagulant). Wet blood films and blood smears (thin and thick) wore made from the collected blood 
samples (The World Assembly of Delegates of the OIE in May 2012), formorphological studies and identification of the Trypanosoma species and microfilaria species.

\section{Wet blood films:}

A small drop of blood $(2-3 \mu \mathrm{l})$ was placed on a clean glass slide and placed over it a cover-slip to spread the blood as a monolayer of cells. Then examined by light microscopy $(200 \times)$ to detect any motile trypanosomes and movement of microfilaria.

\section{Thin smears:}

A small drop of blood $(3-5 \mu \mathrm{l})$ was placed at one end of a clean microscope slide and drawn out a thin film in the usual way. Air-dry briefly and fixed in methyl alcohol for 5 minute and allowed drying. Then we stained the smears in Giemsa stain for 25 minutes. Pour off stain and wash the slide in tap water and dry. Examine at a magnification of (400-1000x) with oil immersion. This technique permits detailed morphological studies and identification of the Trypanosoma species and microfilaria species.

\section{$\underline{\text { Thick smears: }}$}

Place a large drop of blood $(10 \mu \mathrm{l})$ on the center of a microscope slide and spread with a tooth pick or the corner of another slide so that an area of approximately $1.0-1.25 \mathrm{~cm}$ in diameter is covered. Air-dry for 1 hour or longer, while protecting the slide from insects. Place the slide in a horizontal position then stain the unfixed smear with Giemsa's Stain, for 25 minutes. After washing and drying, examine the smears by light microscopy at a magnification of (400-1000x) with oil immersion. 


\section{Tick collection and identification:}

We were examined 2400 camels for ticks infestations (the same camels that blood was been collected) in the same period of the study and collected 960 specimens of ticks from camels (480 male ticks $\& 480$ female ticks). Ticks were collected from animals without damaging their mouth parts (Soulsby, 1982).These specimens were brought to the Laboratory of Parasitology (Animal health research institute - Aswan) for taxonomic identification according to the keys given by (Walker et al., 2007). Ticks were identified to the species level according to Hoogstraal (1956) and Walker et al. (2003), taking into consideration the recent valid names of the genus and species (Barker \& Murrell, 2004).

\section{RESULTS}

In this study annual prevalence of the tick's infestation was founded $(60.96 \%)$ (1463 infested camels /2400 examined camels).

Table (1): prevalence of tick's infestation on camels:

\begin{tabular}{|lccc|}
\hline \multicolumn{2}{|l|}{ Monthexamined camels( male) } & infested camels(male) & \% of infestations \\
\hline January & 200 & 187 & $93.5 \%$ \\
February & 200 & 161 & $80.5 \%$ \\
March & 200 & 139 & $69 \%$ \\
April & 200 & 111 & $55.5 \%$ \\
May & 200 & 61 & $30.5 \%$ \\
June & 200 & 30 & $15 \%$ \\
July & 200 & 39 & $19.5 \%$ \\
August & 200 & 93 & $46.5 \%$ \\
September & 200 & 122 & $61 \%$ \\
October & 200 & 151 & $75.5 \%$ \\
November & 200 & 182 & $91 \%$ \\
December & 200 & 187 & $93.5 \%$ \\
\hline Total & 2400 & 1463 & $60.96 \%$ \\
\hline
\end{tabular}

$\overline{\overline{\text { Kafrelsheikh Vet. Med. J. Vol. } 15 \text { No. } 1 \text { (2017) }}}$ 
We founded that the high prevalence rate of tick's infestation on camels was $(89.2 \%)$ in winter followed by $(75.83 \%)$ in autumn, $(51.83 \%)$ in spring and the low prevalence was $(27 \%)$ in summer. The higher infestation of ticks on camels were recorded in November, December (2015) and January (2016) and lower infestation were recorded in June.

Table (2): seasonal influences of tick's infestations on camels:

\begin{tabular}{|lccc|}
\hline \multicolumn{2}{|l|}{ Season examined camels (male) } & infested camels (male) & $\%$ of infestations \\
\hline Winter & 600 & 535 & $89.2 \%$ \\
Spring & 600 & 311 & $51.83 \%$ \\
Summer & 600 & 162 & $27 \%$ \\
Autumn & 600 & 455 & $75.83 \%$ \\
\hline Total & 2400 & 1463 & $60.96 \%$ \\
\hline
\end{tabular}

Hyalomma dromedarii was found to be the predominant (83.54\%) tick species infesting camels. Other tick species found in very low numbers were Rhipicephalus praetextatus (4.27\%), Hyalommaanatolicum anatolicum (3.85\%), Hyalomma impeltatum (2.92\%), Rhipicephalus sanguineus (2.29\%), Hyalomma anatolicum excavatum (1.35\%), Hyalomma marginatum rufipes (1.12\%), and Hyalommatruncatum $(0.63 \%)$.

Table (3): Ticks species that infest camels:

\begin{tabular}{|c|c|c|c|c|c|c|c|c|c|c|c|c|c|}
\hline Month & Jan. & Feb. & Mar. & Apr. & Ma. & Jun. & Jul. & Aug. & Sep. & Oct. & Nov. & Dec. & Total \\
\hline H.dromedarii & 62 & 68 & 67 & 60 & 62 & 61 & 71 & 72 & 75 & 76 & 60 & 68 & 802 \\
\hline H.impeltatum & 4 & 2 & 4 & 3 & 3 & 1 & 1 & 1 & 1 & 2 & 4 & 2 & 28 \\
\hline H.anatolicum anatolicum & 5 & 3 & 3 & 3 & 3 & 4 & 3 & 1 & 2 & 2 & 5 & 3 & 37 \\
\hline H.anatolicum excavatum & 2 & 2 & 0 & 2 & 1 & 2 & 0 & 0 & 0 & 0 & 1 & 3 & 13 \\
\hline H.marginatum rufipes & 0 & 1 & 0 & 2 & 2 & 3 & 1 & 0 & 0 & 0 & 1 & 1 & 11 \\
\hline H. truncatum & 1 & 0 & 0 & 0 & 0 & 2 & 0 & 3 & 0 & 0 & 0 & 0 & 6 \\
\hline Rh. Praetextatus & 3 & 4 & 4 & 6 & 5 & 3 & 4 & 3 & 2 & 0 & 6 & 1 & 41 \\
\hline Rh. Sanguineus & 3 & 2 & 2 & 4 & 4 & 3 & 0 & 0 & 0 & 0 & 3 & 1 & 22 \\
\hline
\end{tabular}

$\overline{\overline{\text { Kafrelsheikh Vet. Med. J. Vol. } 15 \text { No. } 1 \text { (2017) }}}$ 
Studies On Role Of Ticks In Transmission Of Some ...

Table (4): Ticks species that infest camels (\%):

\begin{tabular}{|c|c|c|c|c|c|c|c|c|c|c|c|c|c|}
\hline Month & Jan. & Feb. & Mar. & Apr. & Ma. & Jun. & Jul. & Aug. & Sep. & Oct. & Nov. & Dec. & Total\% \\
\hline H.dromedarii & 78.75 & 85 & 83.75 & 75 & 77.57 & 6.25 & 88.75 & 90 & 93.75 & 95 & 75 & 85 & 83.65 \\
\hline H.impeltatum & & & 5 & 2.5 & 53.75 & 3.75 & 1.25 & 1.25 & 1.25 & 1.2 & 52.5 & 52.5 & 2.92 \\
\hline H.anatolicum anatolicum & 6.25 & 3.75 & 3.75 & 3.75 & 3.75 & 5 & 3.75 & 1.25 & 2.5 & 2.5 & 6.25 & 3.75 & 3.85 \\
\hline H.anatolicum excavatum & 2.5 & 2.50 & 2.5 & 1.25 & 2.5 & 0 & 0 & 0 & 0 & 1.25 & 3.75 & & 1.35 \\
\hline H.marginatum rufipes & 0 & 1.25 & 0 & 2.5 & 2.5 & 3.75 & 1.25 & 0 & 0 & 0 & 1.25 & 1.25 & 1.12 \\
\hline H. truncatum & 1.25 & 0 & 0 & 0 & 0 & 2.5 & 0 & 3.75 & 0 & 0 & 0 & 0 & 0.63 \\
\hline Rh. Praetextatus & 3.75 & 5 & 5 & 7.5 & 6.25 & 3.75 & 5 & 3.75 & 2.5 & 0 & 7.5 & 1.25 & 4.27 \\
\hline Rh. Sanguineus & 3.75 & 2.5 & 2.5 & 5 & 5 & 3.75 & 0 & 0 & 0 & 0 & 3.75 & 1.25 & 2.29 \\
\hline
\end{tabular}

In this study, the occurrence of Trypanosoma evansi was reported 99 positive samples (2.0625\%)among 4800 examined camels.

Table (5): Prevalence of Trypanosoma evansi infection of the examined camels by blood film smears (Jugular vein):

\begin{tabular}{|lccc|}
\hline MonthBlood & samplesexamined & Blood samples infected & Prevalence\% \\
\hline January & 400 & 0 & $0 \%$ \\
February & 400 & 0 & $0 \%$ \\
March & 400 & 0 & $0 \%$ \\
April & 400 & 18 & $4.5 \%$ \\
May & 400 & 18 & $4.5 \%$ \\
June & 400 & 8 & $2 \%$ \\
July & 400 & 2 & $0.5 \%$ \\
August & 400 & 19 & $4.75 \%$ \\
September & 400 & 0 & $0 \%$ \\
October & 400 & 34 & $8.5 \%$ \\
November & 400 & 0 & $0 \%$ \\
December & 400 & 0 & $0 \%$ \\
\hline Total & 4800 & 99 & $2.0625 \%$ \\
\hline
\end{tabular}

In this present study,we founded that Trypanosoma evansi infection showed the highest prevalence rate in Spring (3\%) followed by Autumn $(2.83 \%)$, Summer $(2.42 \%)$ and low prevalence rate in Winter $(0 \%)$ and also showed the highest prevalence rate of Trypanosoma evansi infection was $8.5 \%$ in October followed by August $4.75 \%$, while the period from November 2015 to March 2016 had the lowest prevalence rate (0\%)and that mean also outbreaks of infection was higher during rainy season (June to October).

$\overline{\text { Kafrelsheikh Vet. Med. J. Vol. } 15 \text { No. } 1 \text { (2017) }}$ 
Table (6): Seasonal influences of Trypanosoma evansi infection of the examined camels by blood film smears (Jugular vein):

\begin{tabular}{|lccc|}
\hline Month Blood & samples examined & Blood samples infected & Prevalence \% \\
\hline Winter & 1200 & 0 & $0 \%$ \\
Spring & 1200 & 36 & $3 \%$ \\
Summer & 1200 & 29 & $2.42 \%$ \\
Autumn & 1200 & 34 & $2.83 \%$ \\
\hline Total & 4800 & 99 & $2.0625 \%$ \\
\hline
\end{tabular}

In this study, the occurrence of microfilaria was reported 2 infected samples in February and December (winter) with prevalence rate $(0.042 \%)$ among 4800 examined camels.

Table (7): Prevalence of Microfilaria infection of the examined camels by blood film smears (Jugular vein):

\begin{tabular}{|lccc|}
\hline MonthBlood samplesexamined & Blood samples infected & Prevalence \% \\
\hline January & 400 & 0 & $0 \%$ \\
February & 400 & 1 & $0.25 \%$ \\
March & 400 & 0 & $0 \%$ \\
April & 400 & 0 & $0 \%$ \\
May & 400 & 0 & $0 \%$ \\
June & 400 & 0 & $0 \%$ \\
July & 400 & 0 & $0 \%$ \\
August & 400 & 0 & $0 \%$ \\
September & 400 & 0 & $0 \%$ \\
October & 400 & 0 & $0 \%$ \\
November & 400 & 1 & $0.25 \%$ \\
December & 400 & 0 & $0 \%$ \\
\hline Total & 4800 & 2 & $0.042 \%$ \\
\hline
\end{tabular}

In this study we examined (480) male of ticks and (480) female of ticks by monthly rate (40) male tick and (40) female tick, we founded two samples in gut of male ticks contain developed stages of Trypanosomaspecies in (March and June).

$\overline{\text { Kafrelsheikh Vet. Med. J. Vol. } 15 \text { No. } 1 \text { (2017) }}$ 


\section{DISCUSSION}

In this study annual prevalence of the tick's infestation was founded (60.96\%) (1463 infested camels /2400 examined camels), and those result in agreement with reported by Moshaverinia \& Moghaddas (2015) (59.25\%) in Iran, Dinka et al., 2010 (61.46 \%) in Eastern Ethiopia. On the contrary, the prevalence rate of ticks infestations obtained in this study was lower than those reported by Lawal et al., 2007 (92.7\%) in Nigeria, Kiros et al., 2014 (96.6 \%) in Tigary-Northern Ethiopia.

We founded that the high prevalence rate of tick's infestation on camels was $(89.2 \%)$ in winter followed by $(75.83 \%)$ in autumn, $(51.83 \%)$ in spring and the low prevalence was $(27 \%)$ in summer. The higher infestation were recorded in November, December (2015) and January (2016) and lower infestation were recorded in June that result in agreement with reported by Ahmed (1999) (higher infestations in winter), El Tigani \& Mohammed (2010) February (cold season), but in contrast of result reported by Diab et al., 2001 that higher infestation in March to November in Egypt, Moshaverinia \& Moghaddas (2015), higher infestations in summer and spring .

Hyalomma dromedariiinpresent studywas found to be the predominant species of ticks been founded $(\mathbf{8 3 . 5 4} \%)$ and that in agreement with reported by $\boldsymbol{E l}$ Tigani \& Mohammed(2010) (69.64\%), Moshaverinia et al., 2013 (70.76 \%), Elghali \& Hassan (2009) (89\%) in Northern Sudan, Van Straten \& Jongejan (1993) ; Diab et al., 2001 (95\%) in Egypt, Karrar et al., 1963 reported that in Sudan and also Osman (1977) in Darfur State , Al Waer (2004) in Libya, Salimabadi et al. 2010 ; Nazifi et al. 2011; Fard et al. 2012 in Iran, in contrast of result reported Kiros et al., 2014 in Tigary -Northern Ethiopia that Rhipicephalus species was predominant $(61.77 \%)$. 
Beside Hyalomma dromedarii, seven species were founded in this present result Rhipicephalus praetextatus (4.27 \%), Hyalomma anatolicum anatolicum (3.85 \%), Hyalomma impeltatum (2.92 \%), Rhipicephalus sanguineus (2.29 \%), Hyalomma anatolicum excavatum (1.35 \%), Hyalomma marginatum rufipes (1.12\%), and Hyalomma truncatum $(0.63 \%)$.

Rhipicephalus praetextatus $(4.27 \%)$ and Hyalomma anatolicum anatolicum (3.85\%) was in agreement with those reported by Elghali \& Hassan (2009) $(0.30 \%) \&(3.3 \%)$ in Northern Sudan respectively. Also reported in camels by Abdel-Shafy (1994; 2000) in Egypt; Diab et al., 2001 reported Hyalomma anatolicum anatolicum in Egypt. Moshaverinia et al., 2013 founded Hyalomma anatolicum anatolicum (4.81\%) in Iran; El Tigani \& Mohammed (2010) reported that Hyalomma anatolicum anatolicum (4.35\%) in El Butana area mideastern Sudan.

Hyalomma impeltatum (2.92\%), was in agreement with those reported by (Steward, 1950; Karrar et al., 1963; Osman, 1977; Latif, 1985; Shommein \& Osman 1987; Yassir et al., 1992) in Sudan, Diab et al., 2001 in Egypt, Moshaverinia et al., 2013 (0.09\%) in Iran , Nazifi et al., 2011 (0.4\%) in Qeshm Island, Iran, El Tigani \& Mohammed (2010) (6.39\%) in El Butana area mid-eastern Sudan, Elghali \& Hassan (2009) $(7.7 \%)$ in Northern Sudan.

Rhipicephalus sanguineus (2.29\%), was in agreement with those reported by Karrar et al., 1963 in Sudan, Pakistan Elghali \& Hassan (2009) (0.09 \%) in Northern Sudan, El Tigani \& Mohammed (2010) $(2.22 \%)$ in El Butana area mid-eastern Sudan, Lawal et al., 2007 in Nigeria. 
Hyalomma anatolicum excavatum (1.35\%), was in agreement with those reported by Moshaverinia et al., 2013 (19.25\%) in Iran, Karrar et al.,1963 in Sudan, Van Straten \& Jongejan (1993); AbdelShafy (1994;2000); Diab et al., 2001 reported that in Egypt, Nazifi et al., $2011(22 \%)$ in Qeshm Island- Iran.

Hyalomma marginatum rufipes (1.12\%), was in agreement with those reported by (Steward, 1950; Karrar et al., 1963; Osman, 1977; Latif, 1985; Shommein \& Osman 1987; Yassir et al., 1992) in Sudan, Elghali \& Hassan (2009) (0.25\%) in Northern Sudan, Van Straten \& Jongejan (1993) in Egypt, El Tigani \& Mohammed (2010) (7.29 \%) in El Butana area mid-eastern Sudan, Lawal et al., 2007 (22.9 \%) in Nigeria, Kiros et al., 2014 (47.4\%) in Tigary -Northern Ethiopia.

Hyalomma truncatum (0.63\%), was in agreement with those reported by (Steward, 1950; Karrar et al., 1963; Osman, 1977; Latif, 1985; Shommein \& Osman 1987; Yassir et al., 1992) in Sudan, Elghali \&Hassan (2009) (0.29 \%) in Northern Sudan, El Tigani \& Mohammed (2010) (0.71 \%) in El Butana area mid-eastern Sudan Kiros et al., 2014 (8.9 \%) in Tigary -Northern Ethiopia, Lawal et al., 2007 (11.9 \%) in Nigeria.

In this study, the occurrence of Trypanosoma evansi was reported 99 positive samples (2.0625\%) among 4800 examined camels this result was in agreement with those reported by Dafalla (1988) (2.04\%) in Gedarif, Ngaira et al 2013 (2.3\%) in eastern Kenya, Birhanu et al.2015 (2.7\%) in Afar-Northern Ethiopia, Abd-Elmaleek et al.2014 (3.06\%) in Assiut-Egypt. But lower than those reported by Zarif-Fard \& HashemiFesharaki (2000) (10\%) in Iran, Mahran (2004) (11.5\%) in Shalatin city -Red sea governorate, Elhaig et al, .2013 (12\%) in Ismailia -Egypt, Kafrelsheikh Vet. Med. J. Vol. 15 No. 1 (2017) 
El-Hewairy et al., 2014 (16.9\%) in Abu-simbuel and Darwa city Aswan governorate, considered higher than that previously recorded by Dafalla (1998) (1.12\%) in Kassala.

In this study, we founded that Trypanosoma evansiinfection showed the highest prevalence rate in Spring (3\%) followed by Autumn $(2.83 \%)$, Summer $(2.42 \%)$ and low prevalence rate in Winter $(0 \%)$ and also showed the highest prevalence rate of Trypanosoma evansiinfection was $8.5 \%$ in October followed by August $4.75 \%$, while the period from November 2015 to March 2016 had the lowest prevalence rate (0\%)and that mean also outbreaks of infection was higher during rainy season(June to October), this was in agreement with those reported by Enwezor \& Sackey (2005). While Elamin et al, 1998 reported that the higher prevalence infection in Sudan was in dry season (November to May) than in wet season (June to October), Mochabo,2003 indicated that highest prevalence of infection in Kenya was occurred immediately after the rainy season as well as in the dry season. Mahran (2004) reported that the highest infection rate in Shalatin city- Egypt was in the summer season but the lowest rate in spring season. Zayed et al, 2010, noticed that higher prevalence rate in Egypt was in winter followed by summer and spring.

In this study, the occurrence of microfilaria was reported 2 infected samples in February and December (winter) with prevalence rate $(0.042 \%)$ among 4800 examined camels. This result was in agreement with those reported by Karimi et al.,2015 (0.88\%) in Central regions of Iran , Al-Khalifa et al., 2009 (1\%) in Riyadh -Saudi Arabia , Sazmand et al., 2015 (2\%) in south-east Iran, Mohammed et al., 2007 (2.32\%) in Shika Zaria -Nigeria. The occurrence of D. evansi in camels was first

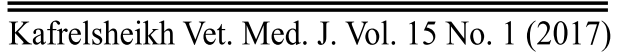


recorded as case reports from Asian countries by Baylis and Daabney (1923) and Boulanger (1924) and from Egypt by Nagaty (1947). Pathak et al. (1998) found microfilaria of D. evansi in both sexes in Rajasthan, India. Moghaddar et al. (1992) reported the occurrence of D. evansi in dromedary camels of Fars Province of Iran for the first time. Infection of camel with this parasite has been also reported from Sudan, the Far East and eastern parts of the farmer USSR, North and East Africa, and in Pakistan (Soulsby 1982; Kaufman 1996; Butt 1995; Pathak et al. 1998; Mahran 2004). The high prevalence of D. evansi was previously reported in certain areas of Russia, Pakistan and Iran (Pathak et al. 1998; Butt 1995; Oryan et al 2008). On the contrary, the occurrence of $\boldsymbol{D}$. evansiobtained in this study was lower than those reported by AbdelRady et al., 2012 (5.9\%) in El-Wady El-gaded (local breed), (Hussein et al., 2009 (6\%)in Eastern regions -Saudi Arabia, Abdul-Salam \& AlTaqui (1995) (11\%) in Kuwait, Sazmand et al., 2013 (12.92\%) in different regions of Iran, Elamin et al.,1993 (7of 14) camels infected by D.evansi in Sudan. In contrast Abdel-Rady et al., 2012 reported that prevalence in imported breed of dromedary camels was $(0 \%)$ by microfilaria infection in Upper Egypt Governorates.

In this study we founded two samples in gut of male ticks contain developmental stages of Trypanosoma in (March and June). This result was in agreement with reported by (Magona et al. 2009; Burgdorfer et al. 1973), that saidTrypanosomes are parasites transmitted by various ticks. (Hussein et al., 2009) also reported that during examination of some ticks for parasites that may infect livestock in Saudi Arabia, Trypanosoma developmental stages were found in the tick Hyalomma dromedarii salivary glands (unpublished data).

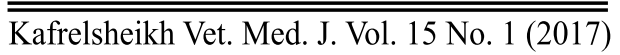




\section{REFERENCES}

- Abd-Elmaleck BS, Abed GH, Mandour AM (2014): Some Protozoan Parasites Infecting Blood of Camels (Camelus dromedarius) at Assiut Locality, Upper Egypt. J Bacterial Parasitol 5:184.

- Abdel-Shafy S (1994): Morphological description of ixodid immature stages and research of blood parasites in farm animals in Egypt. MSc Thesis, Fac. Agric. Cairo Univ. 150 pp.

- Abdel-Shafy S (2000): Microbiological and control studies on ticks infesting farm animals and poultry. PhD. Thesis Fac. Agr. Cairo Univ. 209 pp.

- Abdel-Rady. A, Laila S. Ahmed, Helmy S. Ali and Mohamed ElBashir (2012): Epidemiological studies on camels' filariasis in Upper Egypt. ${ }^{15}$ Scientific Congress, 2012, Faculty of Veterinary Medicine, Assiut Univ., Egypt. pp 57-72.

- Abdul-Salam,J.; Al-Taqui.M (1995): Seasonal prevalence of Onchocerca-like microfilaria in camels in Kuwait1995.J Egypt Soc Parasitol.1995;25(1):19-24.NLM PMID: 7602162

- Alwaer, O.R. (2004): Epidemiology study on camel ticks infestation in Libya and vaccine trials using Boophilus derived vaccine against Hyalomma Dromedarii ticks.( Un published M.SC thesis Institute Agronomique et veterinaire HASSAN 11, Morocco.

- AHMED, B.M. (1999): Studies on epizootiology of Theileria (Lestoquardi Nomen Novum) hirci (Apicomplexa: Theileriidae) in River Nile State. M.Sc. thesis, Nile Valley University.

- Barker SC, Murrell A. (2004): Systematics and evolution of tickswith a list of valid genus and species names. Parasitology 129:15-36. doi:10. 1017/S0031182004005207. 
- Baylis A, Daabney R (1923): Record of the Indian Museum 25:511

- Birhanu H, Fikru R, Said M, Kidane W, Gebrehiwot T, Hagos A, Alemu T, Dawit T, Berkvens D, Goddeeris BM, Buscher P. (2015): Epidemiology of Trypanosoma evansi and Trypanosoma vivax in domestic animals from selected districts of Tigray and Afar regions, Northern Ethiopia. Parasit Vectors. 2015;8:212-30

- Boulanger CL (1924): Dipetalonema evansi in camels. Parasitology $16: 419$

- Burgdorfer W, Schmidt ML, Hoogstraal H (1973): Detection of Trypanosoma theileri in Ethiopian cattle ticks. Acta Trop 30:340-346.

- Butt AA (1995): Prevalence of haemoparasites and evaluation of their diagnostic tests in dromedary. MSc thesis, Department of Veterinary Clinical Medicine and Surgery, University of Agriculture, Faisalabad, Pakistan.

- Central Statistical Agency of Ethiopia (CSA) (2010): Agricultural sample survey report on livestock and livestock characteristics. 11(468):39

- Dafalla, E. I. (1988): A study on incidence of camel trypanosomosis in Kassala province, Sudan. J. Vet. Res., 8: 35-38.

- Desquesnes, M., Holzmuller, P., De-Hua, L., Dargantes, A., Lun, Z.R. \& Jittaplapong, S., (2013): Trypanosoma evansi and Surra: A Review and Perspectives on Origin, History, Distribution, Taxonomy, Morphology, Hosts, and Pathogenic Effects. Biomed Res Int. 2013. http://dx.doi.org/10.1155/2013/194176. 
- Diab, F.M., EL Kady, G.A. \& Shouky, A. (2001): Bionomics of ticks collected from Sinai. 2. Abundance, attachment sites and density of ticks infesting Arabian camels. Journal of Egyptian Society of Parasitology, 31:479-489.

- Dinka. A, Aeyerusalem. B, Yacop. HT (2010): Astudy on mahor ectoparasities of camel in and around Dire Dawa, Eastern Ethiopia. Rev.Med.161(11):498-501.

- Elamin, E., Bashir, E. and Saeed, E., (1998): Prevalence and infection pattern of Trypanosoma evansi in camels in mid-eastern Sudan. Trop. Anim. Hlth. Prod., 30:107-114

- Elghali, A., Hassan, S.M. (2009): Ticks (Acari: Ixodidae) infesting camels in Northern Sudan. Onderstepoort J. Vet. Res.177:76-185.

- Elhaiga. M, Ahmed I. Youssefb, Amal K. El-Gayarc (2013): Molecular and parasitological detection of Trypanosoma evansi in Camels in Ismailia, Egypt Mahmoud . Veterinary Parasitology 198 (2013) 214-218

- El-Hewairy HM, Sahar A, Galal A, Mousa WM (2014): New approach for diagnosis of Trypanosomes evansi in camel (Camelus dromedaries) by ELISA. Life Sci J 11(X).

- El Tigani,Maha .A; Mohammed,A.S (2010): Ticks (Acari: Ixodidae) Infesting Camels in El Butana Area Mid-Central Sudan. Sudan J. Vet. Res. (2010). 25: 51-54

- Enwezor, F. N. C., A. K. B. SACKEY(2005): Camel trypanosomosis a review. Vet. arhiv 75, 439-452, 2005

- Fard SR, Fathi S, Asl EN, Nazhad HA, Kazeroni SS (2012): Hard ticks on one-humped camel (Camelus dromedarius) and their seasonal population dynamics in southeast, Iran. Trop Anim Health Prod 20044:197.

$\overline{\text { Kafrelsheikh Vet. Med. J. Vol. } 15 \text { No. } 1 \text { (2017) }}$ 
- Fassi-Fehri, I M.M (1937): Department of Microbiology, Institute Agronomique et Vétérinaire Hassan II, B.P. 6202, Rabat (Instituts), Morocco. Diseases of camels. Rev. sci. tech. Off. int. Epiz., 1987, 6 (2), 337-354.

- Hashem, M.A; Badawy, A.I.I. (2008): Blood cellular and biochemical Studies on Filariasis of Dogs ,Research Journal of Animal Sciences 2 (5): 128-134, 2008 ISSN:1993-5269 Medwell Journals, 2008.

- Hoogstraal, H. (1956): African Ixodoidea. 1. Ticks of the Sudan with special reference to Equatoria province and with preliminary review of the genera Boophilus Margaopus and Hyalomma. Navy, Bureau of Medicine and Surgeryn Washington D. C. U. S. 1101p.

- Hussein, H.S.; Al-Khalifa, M.S.; Diab, F.M; Khalil, G.M. (2009): Blood parasites of livestock in certain Regions in Saudi Arabia. Saudi Journal of Biological Sciences (2009) 16, 63-67.

- Jongejan F, Ullenberg $\boldsymbol{G}$ (2004): The global importance of ticks. Parasitology 129:3-14. doi:10.1017/S0031182004005967.

- JORGEN. H and BRIAN P. (1990): The epidemiology, diagnosis and control of gastro-intestinal parasites of ruminants in Africa. A Handbook.

- Karimi A, Rahbari S, Yousefi A (2015): Blood parasites of camels from central regions of Iran: comparative evaluation of various detection techniques and serum protein components. J. Adv. Parasitol. 2(1): 1-4. DOI | http://dx.doi.org/10.14737/journal.jap/2014/2.1.1.4 ISSN | 2311-4096 
- Karrar, G., Kaiser, M.N. \& Hoogstraal, H. (1963): Ecology and hostrelationship of ticks (Ixodoidea) infesting domestic animals in Kassala Province, Sudan with special reference to Amblyomma lepidum Donitz. Bulletin of Entomological Research, 54:509-

- Kaufmann J (1966): Parasitic infections of domestic animals: parasites of dromedaries. Birkhaeuser, Basel, p 275

- Kiros.S, Awol.N, Tsegaye.Y, Hadush.B (2014): Hard Ticks of camel in southern zone of Tigray, Northern Ethiopia.Journal of parasitology and vector Biology. Vol. 6 (10), PP. 151-155. Article No :42F66A047857 DoI:10.5897/JPV2014.)162 ISSN 2141-2510

- Latif, A.A. (1985): Insec. Sci. Appl., 6(1): 59-61.

- Lawal.MD, Ameh.IG, Ahmed A. (2007): Some ectoparasities of camelus dromedarius in sokoto,Nigeria.J.Entomol.4:143-148.

- LUCKINS, A. G. (1998): Epidemiology of Surra: Unanswered Questions. J. Protozool. Res. 8, 106-119.

- Magona JW, Walubengo J, Olaho-Mukani W, Jonsson NN, Eisler $M C$ (2009): Diagnostic value of rectal temperature of African cattle of variable coat colour infected with trypanosomes and tick-borne infections. Vet Parasitol 160:301-305.

- Mahran OM (2004): Some studies on blood parasites in camel (Camelus dromedarius) at Shalatin city, Red Sea Governorate. Assiut Vet Med J 50:172-184.

- Mochabo, K.M.O. (2003): Community participatory approaches in the epidemiology and control of trypanosomosis in camels in Turkana District, Kenya. MVEE thesis, University of Nairobi, 89 pages. 
- Moghaddar N, Oryan A, Hanifepour M (1992): Helminths recovered from the liver and lungs of camel with special reference to their incidence and pathogenesis in shiraz, Islamic Republic of Iran. Indian J Anim Sci 62:1018-1023

- Moshaverinia. Ali ; Moghaddas. Elham (2015): Prevalence of tick infestation in dromedary camels (Camelus dromedarius) brought for slaughter in Mashhad abattoir, Iran J Parasit Dis (July-Sept 2015) 39(3):452-455 DOI 10.1007/s12639-013-0367-5

- Mohammed AK, Sackey AKB, Tekdek LB, Gefu JO (2007): Common health problems of the one humped camel (Camelus dromedarius) introduced into sub-humid climate in Zaria, Nigeria. Res J Anim Sci 1:1-5.

- Nagaty HF (1947): Dipetalonema evansi (Lewis, 1882) and its microfilaria from Camelus dromedarius. Parasitology 38:86-92.

- Nazifi S, Tamadon A, Behzadi MA, Haddadi S, Raayat-Jahromi AR (2011): One-humped camels (Camelus dromedaries) hard Ticks infestations in Qeshm Island,Iran. Vet Res Forum 2:135-138.

- Ngaira, J.M., Bett, B., Karanja, S.M., Njagi, E.N.M., (2003): Evaluation of antigen and antibody rapid detection tests for Trypanosoma evansi infection in camels in Kenya. Veterinary Parasitology 114, 131-141

- OIE Terrestrial Manual, (2012): Chapter 2.1.17. Trypanosoma evansi infec-tion (surra).

- Oryan A, Valinezhad A, Bahrami S (2008): Prevalence and pathology of camel filariasis in Iran. Parasitol Res 103:1125-1131 
- Osman, O.M. (1977). Bull. Anim.Hlth. Prod. Afr. 24: 329-333.

- Pathak KML,Singh Y,Harsh DL (1998): Prevalence of Dipetalonema evans in camels of Rajasthan. J Camel Pract Res 5:166-169

- Salim abadi, Y., Telmadarriy, Z, Vatandoost, H، Chinikar, S, Oshaghi, M.A, Moradi, M ‘ Mirabzadeh, V, Ardakan, E, Hekmat, S ، Nasiri, A. (2010): Hard Ticks on Domestic ruminants and their Seasonal Population Dynamics in Yazd Province Iran. Iranian J. Arthropod-Borne Disease, 4:66-71.

- Sazmand, A., Eigner, B., Mirzaei, M., Hekmatimoghaddam, S., Harl, J., Duscher, G.G., Fuehrer, H.-P., Joachim, A. (2015): Molecular identification and phylogenetic analysis of Dipetalonema evansi (Lewis, 1882) in camels (Camelus dromedarius) of Iran. Parasitol Res. DOI: 10.1007/s00436-015-4896-y.

- Shommein, A.M. ; Osman, O.M. (1987): Diseases of camels in the Sudan. Rev. Sci. tech. off. I. E., OIE., 6(2): 481-486.

- Soulsby EJL (1982): Helminths, arthropods and protozoa of domesticated animals, 7th edn. Bailiere, Tindall and Cassel Ltd., London.

- Steward, J.S. (1950): Vet. Rec., 62:835-839. The World Assembly of Delegates of the OIE in May 2012.

- VAN STRATEN, M.; JONJEGAN, F.(1993): Ticks (Acari: Ixodidae) infesting the Arabian camel (Camelus dromedarius) in Sinai, Egypt with a note on acaricidal efficacy of ivermectin. Experimental and Applied Acarololgy, 17:605-612. 
- Walker, A.R., Bouatour, A., Camicas, J.L., Estrada pena, A., Horak, I.G., Latif, A.A., Pegram, R.G. \& Preston, P.M. (2003): Ticks of domestic animals in Africa. A guide to identification of species. Bioscience report, 42 Comiston Drive, Edinburgh EH10 5 QR Scotland, UK.

- Walker AR, Bouattour A, Camicas JL, Estrada-Pena AI, Horak G, Latif AA, Pegram RG, Preston PM (2007): Ticks of domestic animals in Africa. Bioscience Reports, Edinburgh

- Wernery, U.; Kaaden, O. R. (2002): Infectious Diseases of Camelids. Blackwell Science, Berlin.

- Yassir, O.M.; Osman, O.M. and Elamin, T.H. (1992): Insect. Sci. Appl. 13: 565-568.

- Zarif-Fard MR, Hashemi-Fesharaki R (2000): Study on tissue and blood protozoa of camels in southern Iran. J Camel Pract Res 7:193-194

- Zayed, A.A., Habeeb, S.M., Allam, N.A.T., Ashry, H.M.Z., Mohamed, A.H.M., Ashour, A.A., Taha, H.A., (2010): A critical comparative study of parasito-logical and serological differential diagnostic methods of Trypanosoma evansi infections in some farm animals in Egypt. Am.-Eurasian J. Agr. Environ. Sci. 8, 633-642.

$\overline{\text { Kafrelsheikh Vet. Med. J. Vol. } 15 \text { No. } 1 \text { (2017) }}$ 